\title{
Area, elevation and mass changes of the two southernmost ice caps of the Canadian Arctic Archipelago between 1952 and 2014
}

\author{
C. Papasodoro ${ }^{1,2}$, E. Berthier ${ }^{3}$, A. Royer ${ }^{1,2}$, C. Zdanowicz ${ }^{4}$, and A. Langlois ${ }^{1,2}$ \\ ${ }^{1}$ Centre d'Applications et de Recherches en Télédétection, Université de Sherbrooke, Sherbrooke, Québec, Canada \\ ${ }^{2}$ Centre d'Études Nordiques, Québec City, Québec, Canada \\ ${ }^{3}$ Laboratoire d'Etudes en Géophysique et Océanographie Spatiales, Centre National de la Recherche Scientifique (LEGOS - \\ CNRS, UMR5566), Université de Toulouse, 31400 Toulouse, France \\ ${ }^{4}$ Department of Earth Sciences, Uppsala University, 75236 Uppsala, Sweden
}

Correspondence to: C. Papasodoro (charles.papasodoro@usherbrooke.ca)

Received: 16 February 2015 - Published in The Cryosphere Discuss.: 16 March 2015

Revised: 22 July 2015 - Accepted: 25 July 2015 - Published: 7 August 2015

\begin{abstract}
Grinnell and Terra Nivea Ice Caps are located on the southern Baffin Island, Nunavut, in the Canadian Arctic Archipelago. These relatively small ice caps have received little attention compared to the much larger ice masses further north. Their evolution can, however, give valuable information about the impact of the recent Arctic warming at lower latitudes (i.e. $\sim 62.5^{\circ} \mathrm{N}$ ). In this paper, we measure or estimate historical and recent changes of area, elevation and mass of both ice caps using in situ, airborne and spaceborne data sets, including imagery from the Pléiades satellites. The area of Terra Nivea Ice Cap has decreased by $34 \%$ since the late 1950 s, while that of Grinnell Ice Cap has decreased by $20 \%$ since 1952 . For both ice caps, the areal reduction accelerated at the beginning of the 21 st century. The estimated glacier-wide mass balance was $-0.37 \pm 0.21 \mathrm{~m} \mathrm{a}^{-1}$ water equivalent (w.e.) over Grinnell Ice Cap for the 1952-2014 period, and $-0.47 \pm 0.16 \mathrm{~m} \mathrm{a}^{-1}$ w.e. over Terra Nivea Ice Cap for the 1958/59-2014 period. Terra Nivea Ice Cap has experienced an accelerated rate of mass loss of $-1.77 \pm 0.36 \mathrm{~m} \mathrm{a}^{-1}$ w.e. between 2007 and 2014 . This rate is 5.9 times as negative when compared to the 1958/59-2007 period $\left(-0.30 \pm 0.19 \mathrm{~m} \mathrm{a}^{-1}\right.$ w.e. $)$ and 2 times as negative when compared to the mass balance of other glaciers in the southern parts of Baffin Island over the 20032009 period. A similar acceleration in mass loss is suspected for the Grinnell Ice Cap, given the calculated elevation changes and the proximity to Terra Nivea Ice Cap. The recent increase in mass loss rates for these two ice caps is linked to a strong near-surface regional warming and a
\end{abstract}

lengthening of the melt season into the autumn that may be indirectly strengthened by a later freezing of sea ice in the Hudson Strait sector. On a methodological level, our study illustrates the strong potential of Pléiades satellite data to unlock the under-exploited archive of old aerial photographs.

\section{Introduction}

With a glacierized area of $\sim 150000 \mathrm{~km}^{2}$, the Canadian Arctic Archipelago (CAA) is one of the major glacier regions in the world (Pfeffer et al., 2014). In response to recent Arctic warming (Tingley and Huybers, 2013; Vaughan et al., 2013; Comiso and Hall, 2014), glaciers in the CAA have experienced an acceleration in their mass loss. For the southern parts of the CAA, annual thinning of glaciers has doubled between the historical (1963-2006) and recent (2003-2011) periods (Gardner et al., 2012). Over the entire CAA, the rate of mass change has tripled between 2004 and 2009, reaching $-92 \pm 12 \mathrm{Gt} \mathrm{a}^{-1}$ during the period 2007-2009 (Gardner et al., 2011), making this region one of the main contributors to eustatic sea-level rise for this period, after Greenland and Antarctica (Gardner et al., 2013; Vaughan et al., 2013). Continued monitoring of CAA glaciers is thus critical.

Located in the southeastern part of the CAA, Baffin Island is the largest island of the archipelago (Andrews et al., 2002) and has a total ice-covered area of $\sim 37000 \mathrm{~km}^{2}$. In addition to two major ice caps, Barnes $\left(\sim 5900 \mathrm{~km}^{2}\right)$ and Penny $\left(\sim 6400 \mathrm{~km}^{2}\right)$, Baffin Island is also covered by a num- 
ber of isolated icefields and small ice caps, including Grinnell Ice Cap (GRIC) and Terra Nivea Ice Cap (TNIC) on Meta Incognita Peninsula, at the southernmost tip of the island (Fig. 1). Compared to Barnes and Penny Ice Caps, GRIC and TNIC have received little scientific attention so far (Andrews et al., 2002). Different in situ geophysical measurements were carried out in the 1950s (Blake, 1953; Mercer, 1956), and in the 1980s by teams from the University of Cambridge and the University of Colorado (Dowdeswell, 1982, 1984). Under the supervision of veteran Norwegian glaciologist Dr. Gunnar Østrem, other measurements were conducted on GRIC in the early 1990s by a scientific team from Bates College (Maine, USA) and Nunavut Arctic College. Later in 2003-2004, glaciologists from the Geological Survey of Canada carried out in situ measurements on GRIC (Global Navigation Satellite System (GNSS) elevation measurements, automatic weather observations, snow depth and surface mass balance measurements) with the objective of establishing a long-term observing site. However, consistent prohibitive weather conditions coupled with difficult access to the ice cap led to the cancellation of the project (Zdanowicz, 2007). A recent study (Way, 2015) analyzed changing rates of glacier recession for GRIC and TNIC since the 1950s using historical aerial photographs, satellite (Landsat) imagery and digital elevation models (DEMs). In the present study, we supplement these results by presenting a comprehensive analysis of historical and recent fluctuations of area, surface elevation and mass for GRIC and TNIC over the period 1952-2014. This is done by combining data from spaceborne instruments (laser altimetry and optical stereo imagery), DEMs, airborne imagery (air photos) and in situ GPS surveys. Our analysis differs from that of Way (2015) in the choice of photos, DEMs, and spaceborne, remotely sensed data used to determine glacier change. In particular, we explored the use of sub-meter resolution stereo pairs obtained from the Pléiades satellites to derive DEMs and to collect accurate, numerous and homogeneously distributed ground control points (GCPs) for the photogrammetric processing of aerial photos. We place our findings in the context of the observed pattern of regional glacier changes across the CAA, and discuss climatic forcing factors of particular relevance for the southernmost Baffin Island region.

\section{Study area}

GRIC and TNIC (Fig. 1) are located on Meta Incognita Peninsula, $200 \mathrm{~km}$ south of Iqaluit, Nunavut. GRIC $\left(62.56^{\circ} \mathrm{N}, 66.79^{\circ} \mathrm{W}\right)$ covers an area of $107 \mathrm{~km}^{2}$ (August 2014; this study) with the highest elevations reaching $800 \mathrm{~m}$ a.s.l. (above sea level). On the northeast side, some outlet glaciers extend to Frobisher Bay, which opens into the Labrador Sea. TNIC $\left(62.27^{\circ} \mathrm{N}, 66.51^{\circ} \mathrm{W}\right)$ is located $\sim 17 \mathrm{~km}$ south of the GRIC. It covers an area of approximately $150 \mathrm{~km}^{2}$ (August 2014; this study) with a similar el-

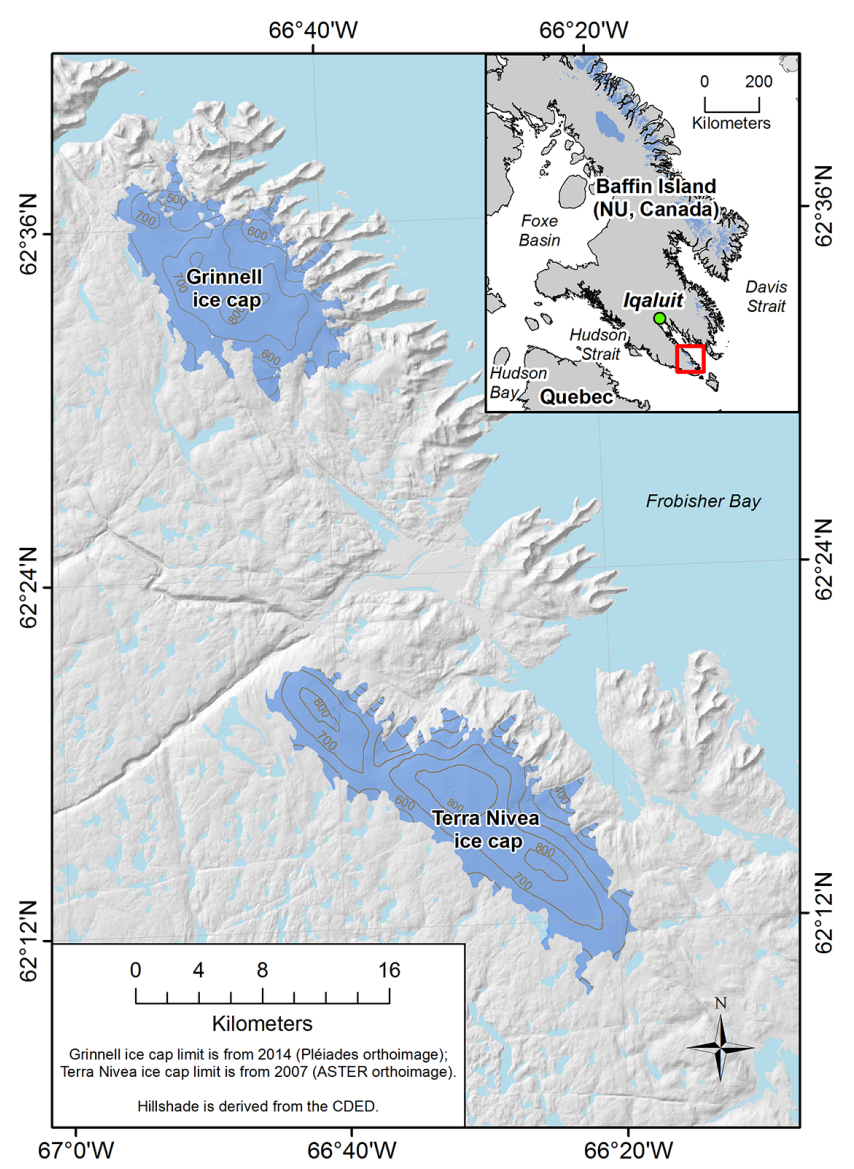

Figure 1. Study area.

evation range as GRIC. Mercer (1954) suggested three factors supporting the continued presence of plateau ice caps on Meta Incognita Peninsula: (1) cool summers, (2) frequent low-level cloud and (3) heavy snowfall. Data from the permanent weather station in Iqaluit (34 $\mathrm{m}$ a.s.l.) indicate that winter temperatures (DJF) in this region averaged $-24^{\circ} \mathrm{C}$ over the past 60 years, while mean summer temperatures (JJA) averaged $6.5^{\circ} \mathrm{C}$. Total annual precipitation is $\sim 500 \mathrm{~mm}$ (snow: $\sim 300 \mathrm{~mm}$; rain: $\sim 200 \mathrm{~mm}$ ). Field observations in winter 2003-04 found no firn at the summit of GRIC, and the estimated winter snow accumulation there $(\sim 2-3 \mathrm{~m}$ snow; or $\sim 0.65-0.75 \mathrm{~m}$ water equivalent) was approximately equal to the amount of melt in summer (Zdanowicz, 2007). Hence the summit of the GRIC is probably close, or slightly below, the present-day equilibrium line altitude (ELA), making it highly susceptible to experience net mass losses (Pelto, 2010).

Observations from various expeditions in the 1950s revealed that the western margin of GRIC was relatively stable, but that coastal outlet glaciers (eastern margin) were shrinking moderately when compared to photographs from 1897 (Mercer, 1954, 1956). Moraines studied near both ice caps in the early 1980s indicated that the most recent phase of recession dated from the last 100 years, and that both ice caps 


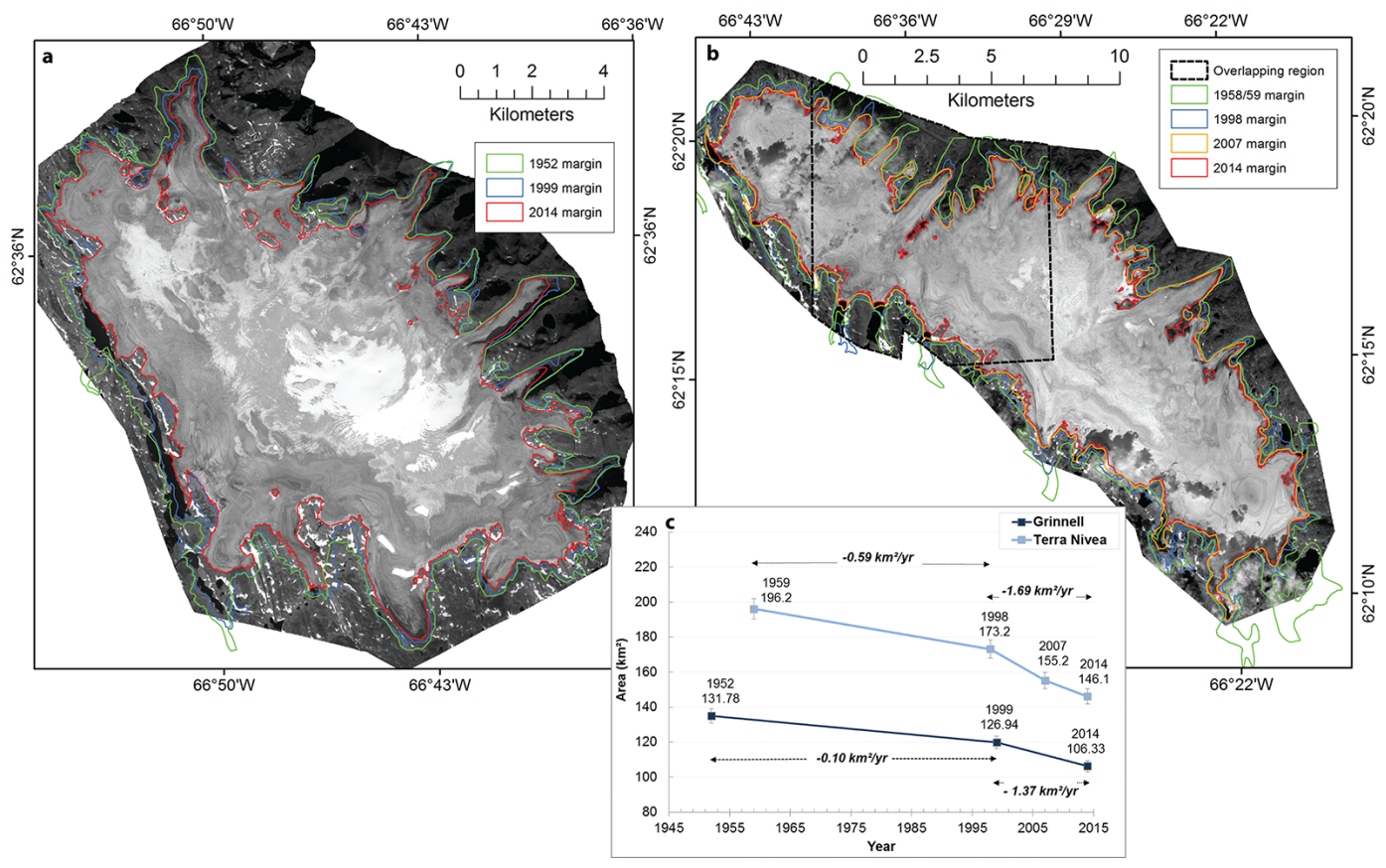

Figure 2. (a) Pléiades orthoimage of Grinnell Ice Cap (3 August 2014) superimposed with areal extents from 1952, 1999 and 2014. (b) Pléiades orthoimages of Terra Nivea Ice Cap (14 August 2014 on the east side and 26 August 2014 on the west side) superimposed with areal extents from 1958/59, 1998, 2007 and 2014. The overlapping area between the two orthoimages is represented by the black dashed polygon. (c) Historical and recent area changes for both ice caps. Error margins were estimated at $5 \%$ for historical areas and at $3 \%$ for 1998 and later outlines (Sect. 4.4.3.).

probably reached their largest areal extent during the Little Ice Age cold climate interval (Muller, 1980; Dowdeswell, 1982, 1984; Andrews, 2002). Dowdeswell (1982) estimated that the outlet glacier of GRIC that calves into Watts Bay extended much further out a few centuries earlier, but also reported that another outlet glacier to the south of the ice cap was advancing.

\section{Data}

\subsection{Pléiades stereoscopic images}

Launched on 17 December 2011 and 2 December 2012 respectively, the Pléiades $1 \mathrm{~A}$ and $1 \mathrm{~B}$ satellites have recently shown their high potential for glacier DEM extraction and thus, for mass balance estimations (Wagnon et al., 2013; Berthier et al., 2014; Marti et al., 2015). The two satellites follow the same near-polar sun-synchronous orbit and provide panchromatic and multispectral imagery at a very high ground spatial resolution, $0.7 \mathrm{~m}$ for panchromatic and $2.8 \mathrm{~m}$ for multispectral images, respectively (Astrium, 2012). Both satellites have independent stereoscopic capabilities. The fact that the panchromatic band images derived from Pléiades satellites are coded in 12 bits represents a clear advantage on a glacier surface (especially over the low contrast accumulation area), given the fact that a large radiometric range provides better contrast and reduces the risk of image saturation (Berthier et al., 2014).

Three stereoscopic pairs were acquired over our study area (Table 1): one for GRIC (3 August 2014) and two for TNIC (14 August 2014 for the eastern part and $26 \mathrm{Au}-$ gust 2014 for the western part, with an overlapping area of $84 \mathrm{~km}^{2}$ ). The stereoscopic pair covering GRIC is cloud-free, while a few clouds $(<10 \%$ of the scene) were present over TNIC during scene acquisitions (Fig. 2). Acquisitions were made at the end of the ablation season to ensure a maximum degree of surface texture (Berthier and Toutin, 2008). Each image was provided with Rational Polynomial Coefficients (RPCs), which allows geometric modeling without GCP. Stereoscopic pairs were used (1) for DEM generation on both ice caps and (2) for GCP extraction for the photogrammetric processing of the historical aerial photos on GRIC (see Sect. 4.2).

\subsection{Historic Canadian Digital Elevation Data}

Historic Canadian Digital Elevation Data (CDED, Natural Resources Canada), provided at a scale of $1: 50 \mathrm{k}$, were acquired for the two ice caps. These elevations were derived by stereo-compilation of aerial photos acquired during the summers of 1958 and 1959. Raw elevations are orthometric and referenced to the Canadian Gravitational Vertical Model of 1928 (CGVD1928). The average elevation differ- 
Table 1. Elevation data sets used in this study with the acquisition date and the purpose of their use for each ice cap.

\begin{tabular}{|c|c|c|c|}
\hline Ice cap & Elevation data set & Acquisition date & Purpose \\
\hline \multirow{6}{*}{ Grinnell } & $\begin{array}{l}\text { Photogrammetry } \\
\text { derived DEM }\end{array}$ & 21-22 August 1952 & $\begin{array}{l}\text { Historical mass balance } \\
\text { and } \mathrm{d} H\end{array}$ \\
\hline & CDED & 6 September 1958 & Absolute co-registration \\
\hline & \multirow[b]{2}{*}{ ICESat points } & All laser periods outside glacier & Absolute co-registration \\
\hline & & $\begin{array}{l}\text { Nov 2003, Mar 2004, Mar 2005, Nov 2005, } \\
\text { Mar 2006, Nov } 2006 \text { and Apr } 2007 \\
\text { (on glacier) }\end{array}$ & Recent $\mathrm{d} H$ \\
\hline & In situ GPS points & April 2004 & Recent $\mathrm{d} H$ \\
\hline & Pléiades DEM & 3 August 2014 & $\begin{array}{l}\text { Historical mass balance; } \\
\text { historical and recent } \mathrm{d} H\end{array}$ \\
\hline \multirow{6}{*}{ Terra Nivea } & CDED & $\begin{array}{l}6 \text { September } 1958 \text { (West part) and } \\
4 \text { August } 1959 \text { (East part) }\end{array}$ & $\begin{array}{l}\text { Historical mass balance and } \\
\mathrm{d} H \text {, absolute co-registration }\end{array}$ \\
\hline & \multirow{3}{*}{ ICESat points } & All laser periods outside glacier & Absolute co-registration \\
\hline & & Apr and Nov 2007 (on glacier) & Evaluation of ASTER DEM \\
\hline & & $\begin{array}{l}\text { Nov 2003, Mar 2004, Mar 2005, Nov 2005, } \\
\text { Mar 2006, Nov } 2006 \text { and Apr } 2007 \\
\text { (on glacier) }\end{array}$ & Recent $\mathrm{d} H$ \\
\hline & ASTER DEM & 3 August 2007 & Recent mass balance and $\mathrm{d} H$ \\
\hline & Pléiades DEM & $\begin{array}{l}14 \text { August } 2014 \text { (West part) and } \\
26 \text { August } 2014 \text { (East part) }\end{array}$ & $\begin{array}{l}\text { Historical and recent } \\
\text { mass balance and } \mathrm{d} H\end{array}$ \\
\hline
\end{tabular}

ences and their standard deviation (SD) between CDED and ICESat laser altimetry were previously calculated off-glacier for 340 CDED maps tiles covering Baffin Island and were reported to be 1.1 and $5.1 \mathrm{~m}$, respectively (Gardner et al., 2012). Here, CDED were used (1) as historical elevations for TNIC and (2) elevations of the surrounding ice-free terrain were used for absolute co-registration for both ice caps (see Sect. 4.3). Artefacts (unrealistic elevations) located in the accumulation area of TNIC were manually identified and deleted using a shaded relief image derived from the DEM. These artefacts were likely due to the poor contrast and low texture of the 1958/59 aerial photos used to generate the CDED.

\subsection{Historical aerial photos}

Historic aerial photos covering GRIC were obtained through the Canadian National Air Photo Library (Natural Resources Canada). We used 24 photos acquired at the end of the ablation season, on 21 and 22 August 1952. A Williamson Eagle IX Cone 524 camera type with a focal length of $152.15 \mathrm{~mm}$ was used and the flight altitude was $16000 \mathrm{ft}$ ( $\sim 4877 \mathrm{~m})$. The photos are distributed in 3 parallel flight lines with an overlapping coverage of $\sim 30 \%$ between each line and $\sim 60 \%$ between two photos of a same line. These photos, exceptional in their quality of detail and texture, were used for the extraction of historical elevations on GRIC and were preferred to the CDED for this ice cap. In fact, the CDED covering GRIC contained major artefacts (i.e. much larger than for TNIC) in the large snow-covered accumulation zone where the texture was particularly weak on the 1958 photos and thus, was not suitable for historical elevations of this ice cap.

\subsection{ICESat altimetric points}

Surface elevation profiles (GLA14, Release 634) collected by the Geoscience Laser Altimetry System (GLAS) onboard ICESat were acquired (Zwally et al., 2002). Each laser pulsederived footprint corresponds to field-of-view with a diameter of $\sim 65 \mathrm{~m}$ and a spacing of $172 \mathrm{~m}$ between each footprint (Schutz et al., 2005). ICESat elevations were converted from their original Topex/Poseidon ellipsoid to the WGS84 ellipsoid using tools provided by the National Snow and Ice Data Center. The entire data set (2003 to 2009) was used for absolute co-registration on ice-free terrain, while the data collected during a few selected dates (Table 1) were used to estimate recent elevation changes and to assess the precision of the ASTER August 2007 DEM (see below). 


\subsection{ASTER DEM}

Products derived from the ASTER satellite mission have been widely used for glaciological studies (e.g. Kääb, 2008; Nuth and Kääb, 2011; Das et al., 2014). To estimate the recent mass balance for TNIC, we used a DEM (product AST14DMO) generated from an ASTER stereo pair acquired on 3 August 2007. The DEM was automatically derived from bands $3 \mathrm{~N}$ (nadir-viewing) and 3B (backwardviewing) that have an intersection angle of $27.6^{\circ}$, which corresponds to a base-to-height ratio of 0.6 (Fujisada et al., 2005). The raw DEM was provided with a grid spacing of $30 \mathrm{~m}$, and elevations are orthometric to the EGM96 geoid. Using 57 ICESat points from two different time periods, namely a few months before (April 2007) and after (November 2007) the ASTER acquisition, we assessed a vertical precision of $2.5 \mathrm{~m}$ (SD) on TNIC for this ASTER DEM. Due to cloud coverage, no suitable ASTER DEM was available for GRIC at the end of the ablation season.

\subsection{In situ GPS measurements}

In April 2004, a team from the Geological Survey of Canada measured three surface elevation profiles at $50 \mathrm{~m}$ horizontal intervals using a Trimble ${ }^{\circledR}$ high-precision Real-Time Kinematic GPS system on the southeast, west and northwest sides of GRIC, and at the front of one of its outlet glaciers (Zdanowicz, 2007). Data acquisition was made using a fixed base station on a geodetic benchmark monument, and GPS positions were subsequently processed with the Canadian Center for Remote Sensing's Precise Point Positioning (PPP) System to obtain an accuracy of a few centimeters. For this paper, those transects were used for recent elevation change calculations. Elevations derived from those GPS measurements are referenced to the GRS80 ellipsoid which can be assumed equal to the WGS84 ellipsoid (sub-mm differences).

\subsection{Glacier outlines}

Various data sets have been used to extract the areal extent of the two ice caps at the end of the ablation season (August/September). For GRIC, three data sets from different dates were used. The 1952 outline was derived manually from the orthorectified historical aerial photos. For 1999, we used the ice cap contour from the Randolph Glacier Inventory (RGI 3.2; Pfeffer et al., 2014), which originates from the Canadian CanVec data set for this region, itself derived from a September 1999 Landsat 7 image. We manually digitized the 2014 margin from the orthorectified panchromatic Pléiades image. For TNIC, outlines were derived for four different dates. We used the raw vectors from the $1: 250 \mathrm{k}$ Canadian National Topographic Data Base as the 1958/59 boundary. Anomalies were found in the delineation of the 1999 margin from the RGI 3.2 (i.e. off-glacier snow patches erroneously included). As an alternative, we manually digi- tized the ice cap margin using a $30 \mathrm{~m}$ resolution Landsat 5 image acquired on August 1998. The August 2007 limit was manually traced from an ASTER orthoimage $(15 \mathrm{~m}$ resolution) provided with the on-demand AST14DMO product, while the 2014 margin was extracted from the orthorectified panchromatic Pléiades images (East and West). To overcome the cloudiness on the Pléiades orthoimages $(\sim 20 \%$ of the ice cap outline obscured by clouds), we used a Landsat 8 panchromatic ( $15 \mathrm{~m}$ of resolution) image also acquired in August 2014. The uncertainty assessment of the outlines is presented in Sect. 4.4.3.

\subsection{Meteorological and sea ice records}

To quantify changes in the regional climate of the southern Baffin Island region over the period covered in our study, air temperature records were retrieved from the Adjusted and Homogenized Canadian Historical Climate Data of the Iqaluit weather station for the period 1950-2014 (Vincent et al., 2002). This is the permanent weather station in the eastern Canadian Arctic with the most continuous records, extending back to 1946. In addition, time series of sea ice cover area for Hudson Strait and Davis Strait were obtained from the Canadian Ice Service archives over the 1968-2014 period.

\section{Methods}

\subsection{Pléiades DEM generation}

The Pléiades DEMs were generated using the OrthoEngine module of Geomatica 2013. No GCP were available for the geometric correction so we relied on the RPCs provided with the images. Adding GCP does not improve the vertical precision of the Pléiades DEM, but can reduce the vertical bias (Berthier et al., 2014). The latter bias can be corrected over ice-free terrain when a good reference data set, such as ICESat, is available (Nuth and Kääb, 2011).

The following steps of DEM extraction were repeated for the three Pléiades stereoscopic pairs. First, we collected 20 tie points (TPs) outside and six on the ice cap. Collecting well-distributed TPs was found to improve the relative orientation between the two images providing increased coverage (Berthier et al., 2014). The following processing parameters were used for DEM extraction: the relief type was set to Mountainous and the DEM detail to Low. No interpolation was performed to fill data gaps. Finally, the DEMs were geocoded with a pixel size of $4 \mathrm{~m}$.

Since the ice-free zones on our Pléiades DEM were not large enough to calculate an elevation accuracy with a sufficient number of ICESat points, we report here the vertical precisions obtained in recent glaciological studies. Wagnon et al. (2013) measured a precision of $1 \mathrm{~m}$ (SD) on a glacier surface in Himalaya using Pléiades DEM. Berthier et al. (2014) also obtained a precision ranging between 0.5 and 
$1 \mathrm{~m}$ (SD), highlighting the consistent precision over glacier surfaces. This precision was shown to be mostly correlated with slope. For the small Ossoue Glacier (French Pyrénées), the precision was slightly lower at $1.8 \mathrm{~m}$ (Marti et al., 2015). A similar vertical precision is expected here.

\subsection{Aerial photos DEM generation}

Photogrammetry is widely used in glaciological studies for reconstructing glacier surface prior to the modern satellite era (Fox et Nuttall, 1997; Barrand et al., 2009). In this study, a 1952 DEM of GRIC was created from historical air photos using OrthoEngine. This software uses a mathematical model compensating for both terrain variations and inherent camera distortions (PCI Geomatics, 2013). A typical photogrammetric procedure was then followed to compute the model, solving the least-square bundle adjustment.

Collecting effective GCPs for photogrammetry in mountainous or polar regions remains one of the main difficulties, especially for archive photos (Barrand et al., 2009). To overcome this difficulty, Pléiades-derived products (DEM and orthoimage) were used to collect GCPs. For each aerial stereoscopic model partially covering the surrounding ice-free terrain, 3 to 7 GCPs were collected outside the ice cap on topographic or geomorphologic structures visible on both the Pléiades orthoimage and the aerial photographs. In order to strengthen the mathematical model, every GCP was collected as stereo GCP (i.e. was identified in all possible aerial photographs). A total of 39 stereo GCPs were collected resulting in 106 GCPs. Also, 6 to 10 widely-dispersed TPs were collected for each aerial stereoscopic model. For the models situated in the middle of the photogrammetric block and covering only the ice cap (no ice-free terrain), only TPs were collected in order to connect them to the photogrammetric block. After the final bundle adjustment, the resulting residual averages of all the GCPs were $2.85 \mathrm{~m}$ in $X, 2.74 \mathrm{~m}$ in $Y$ and $2.68 \mathrm{~m}$ in $Z$. TPs residuals were $1.84 \mathrm{~m}$ in $X$ and $2.15 \mathrm{~m}$ in $Y$. The generated global DEM was geocoded with a grid resolution of $10 \mathrm{~m}$ and no interpolation of data gaps was performed.

Validation of the resulting DEM (before co-registration) against 76 ICESat points on ice-free terrain showed a mean offset of $-3.29 \mathrm{~m}$ (DEM above ICESat in elevations) and a SD of $4.96 \mathrm{~m}$. Between the Pléiades DEM and the 1952 DEM (co-registered together, see Sect. 4.3), the SD of the elevation difference on ice-free terrain was $13.8 \mathrm{~m}$. In total, $66 \%$ of GRIC area was extracted, with data gaps concentrated at the highest elevations in the texture-less accumulation area.

\subsection{DEM adjustments and co-registrations}

DEM co-registration is of primary importance before performing any DEM-based volume change calculations (Nuth and Kääb, 2011). This 3-D co-registration method uses the relationship between aspect, slope and elevation differences over ice-free terrain (Nuth and Kääb, 2011). The Pléiades images only included a small corridor $\left(\sim 20 \mathrm{~km}^{2}\right)$ of icefree terrain near the ice caps (Fig. 2). This corridor coincides with a limited number of cloud-free ICESat points (less than 100 points sparsely distributed around each ice cap) so that a direct co-registration between the Pléiades DEMs and the ICESat points was not optimal. Instead, the CDED tile encompassing the two ice caps was first co-registered with $\sim 1000$ ICESat points over ice-free zones. All other DEMs were then 3-D co-registered to the corrected CDED, independently for each ice cap. Thus, the corrected data sets were all referenced to the WGS84 ellipsoid. To evaluate the consistency of the corrections, the offsets over ice-free terrain between each corrected DEM and the corresponding ICESat points were examined. The offset was below $1.5 \mathrm{~m}$ in each case, suggesting that the absolute co-registration was well conducted and that the effect of geoid variations (CGVD1928 and EGM96 vs. WGS84) was negligible. However, one must interpret these results with caution given the sparsely distributed and limited number of ICESat points (less than 100) over moderate to hilly terrain.

The two independently co-registered Pléiades DEMs of TNIC (14 and 26 August) were compared in their overlapping zone of $84 \mathrm{~km}^{2}$ (Fig. 2). The offset measured over the ice-free terrain was $-0.1 \pm 2.1(\mathrm{SD}) \mathrm{m}$, while an average elevation difference of $0.64 \pm 2.2$ (SD) $\mathrm{m}$ was measured over the ice cap, probably due to the thinning between 14 and 26 August. These results confirm the robustness of the 3-D co-registration using the corrected CDED.

\subsection{Elevation changes and mass balance calculations}

\subsubsection{Elevation changes along ICESat and GPS tracks}

For both Grinnell and Terra Nivea Ice Caps, recent elevation changes were measured between 6 ICESat tracks from different laser overpass periods (autumn 2003 to winter 2007) and the 2014 Pléiades DEMs. For GRIC only, elevation changes were also calculated between the April 2004 in situ GPS transects and the 2014 Pléiades DEM. We did not attempt to compute glacier-wide volume or mass changes from those recent elevation changes measurements since (1) they are sparse and only cover a small fraction of the two ice caps and (2) the GPS and some of the ICESat data were acquired at the end of winter, and limited data were available to apply a seasonal correction. Nevertheless, those recent elevation changes along selected tracks were used to complement the differential DEM analysis described below.

\subsubsection{DEM-derived elevation changes and mass balances}

The geodetic method was applied in order to calculate glacier-wide elevation and mass balances from the DEMs. The following steps were performed for each calculation. 
First, the co-registered DEMs were subtracted to obtain maps of elevation changes $(\mathrm{d} H)$ and change rates $(\mathrm{d} H / \mathrm{d} t)$ after dividing by the interval time $(\mathrm{d} t)$. The $\mathrm{d} H$ values were binned into $50 \mathrm{~m}$ elevation bands and averaged after applying a three sigma filter to exclude outliers (Gardner et al., 2012; Gardelle et al., 2013). Pixels with missing data were replaced with the mean $\mathrm{d} H$ of the corresponding elevation band. Total volume change for each ice cap $(\mathrm{d} V)$ was then determined by summing volume changes from all elevation bands $(n)$ as follows:

$\mathrm{d} V=\sum_{i}^{n}\left(\Delta H_{i} \cdot A_{i}\right)$,

where $i$ corresponds to an elevation band of $50 \mathrm{~m}, \Delta H$ is the mean elevation change measured at elevation band $i$ and $A_{i}$ is the area of the elevation band. In this calculation, the ice cap hypsometry is based on the $1: 250 \mathrm{k}$ CDED (1958/59), while the ice cap limit conforms to the year of the oldest DEM used in the calculation. Our own sensitivity tests have shown that the choice of the DEM used has a very low impact on the mass balance calculation $\left(<0.01 \mathrm{~m} \mathrm{a}^{-1}\right.$ w.e. $)$, as was also demonstrated in Gardner et al. (2011).

The area-averaged change in elevation over the entire ice cap (glacier-wide), $\mathrm{d} H / \mathrm{d} t_{\mathrm{avg}}$, was then calculated as follows:

$\mathrm{d} H / \mathrm{d} t_{\mathrm{avg}}=\frac{\mathrm{d} V}{(\bar{A} \cdot \Delta t)}$,

where $\bar{A}$ is the mean of the initial and final ice cap areas, and $\Delta t$ is the time interval between the two DEMs. Note that $\mathrm{d} H / \mathrm{d} t$ (elevation change rate from co-registered DEM subtraction) must be distinguished from $\mathrm{d} H / \mathrm{d} t_{\mathrm{avg}}$.

Finally, the area-averaged specific geodetic mass balance rate ( $\mathrm{m} \mathrm{a}^{-1}$ w.e.), $\mathrm{d} M / \mathrm{d} t$, was calculated as follows:

$\mathrm{d} M / \mathrm{d} t=\mathrm{d} H / \mathrm{d} t_{\mathrm{avg}} \cdot \rho$,

where $\rho$ is the firn and/or ice density. For the historical mass balance of both ice caps, we used $\rho=850 \mathrm{~kg} \mathrm{~m}^{-3}$ (Huss, 2013), while we used $\rho=900 \mathrm{~kg} \mathrm{~m}^{-3}$ for the recent period on TNIC (2007-2014). The former value of $\rho$ was chosen assuming that there was a firn zone on the ice cap during the last 6 decades, while a visual interpretation of our images (not shown here) suggests the absence of a significant firn zone after 2007. For the sake of readability, the area-averaged specific geodetic mass balance rate (Cogley et al., 2011) is hereafter simply referred to as mass balance or glacier-wide mass balance.

\subsubsection{Accuracy assessment}

The main sources of uncertainty in our mass balance estimates are related to uncertainties in the elevation change measurements, the ice cap limits and the density used to convert volume to mass changes. For historical measurements, elevation change uncertainty was assumed equal to the standard deviation over stable terrain between the two coregistered DEMs (GRIC 1952-2014: 13.8 m; TNIC 1958-2007: 9.6 m; TNIC 1958-2014: $9 \mathrm{~m}$ ), assuming that elevation errors were $100 \%$ correlated. This is a conservative approach that takes into account both the highly correlated CDED elevation errors (Gardner et al., 2012) and the possible errors associated to the aerial photos-derived DEM (i.e. artefacts and low coverage at higher altitudes).

Spatial autocorrelation between the ASTER 2007 and Pléiades 2014 DEMs was analyzed on ice-free terrain to better characterize the elevation change uncertainty in the recent mass balance estimation on TNIC. A low autocorrelation distance $(<100 \mathrm{~m})$ was found between the two elevation products. Applying standard principles of error propagation (e.g. Zemp et al., 2013), we found a very low $( \pm 0.1 \mathrm{~m})$ uncertainty for the elevation change averaged over the entire ice cap. Because we consider this value to be likely underestimated, we conservatively assumed that the uncertainty for the elevation changes was equal to the quadratic sum of the two DEMs uncertainties $( \pm 1 \mathrm{~m}$ for the Pléiades DEM from Berthier et al. (2014) and $\pm 2.5 \mathrm{~m}$ for the ASTER DEM from its comparison to ICESat nearly simultaneous on the ice cap), assuming that (1) the elevation errors are fully correlated within each DEM and that (2) errors of the two DEMs are independent.

For ice caps outlines of 1998 and later, we estimated an error of $3 \%$. This estimate includes possible image interpretation errors $(<2 \%$ of each ice cap extent) and the impact of the image resolution used for outline delimitation $(<1 \%$ of each ice cap extent). Since the ice caps were not covered by debris, interpretation errors were mainly related to the presence of snow-covered surfaces (i.e. snow patches) around each ice cap that may be misinterpreted as ice. The error attributed to the image resolution was established from a comparison analysis made between the Pléiades and Landsat 8-derived TNIC outlines, for which a small difference in extent was obtained $(<1 \%)$. The total uncertainty of $3 \%$ was used for mass balance estimation as well as for area change analysis. For the older (pre-1998) ice cap outlines, a more conservative error of $5 \%$ was applied to take into account the more difficult image interpretation between ice cap limits and snow patches. Those uncertainties are comparable to those reported in Paul et al. (2013) and Winsvold et al. (2014). Finally, an uncertainty of $\pm 60 \mathrm{~kg} \mathrm{~m}^{-3}$ (Huss, 2013) was assigned to the density factor when estimating the historical mass balance on both ice caps and of $\pm 17 \mathrm{~kg} \mathrm{~m}^{-3}$ (Gardner et al., 2012) for the recent estimation on TNIC. 


\section{Results}

\subsection{Area changes}

Areal changes measured for Grinnell and Terra Nivea ice caps since the 1950s are shown in Fig. 2. GRIC experienced a mean rate of areal change of $-0.10 \pm 0.01 \mathrm{~km}^{2} \mathrm{a}^{-1}$ between 1952 and 1999, whereas a mean rate of $-0.59 \pm 0.03 \mathrm{~km}^{2} \mathrm{a}^{-1}$ is measured for TNIC between 1958/59 and 1998. These rates of area change have been significantly more negative since 1998/99 reaching $-1.37 \pm 0.04 \mathrm{~km}^{2} \mathrm{a}^{-1}$ for GRIC and $-1.69 \pm 0.05 \mathrm{~km}^{2} \mathrm{a}^{-1}$ for TNIC. For GRIC, the 2014 areal extent is about $20 \%$ smaller than in 1952, while TNIC area shrank by $34 \%$ between 1958/59 and 2014.

\subsection{Elevation changes}

Maps of historical and recent elevation change rates $(\mathrm{d} H / \mathrm{d} t)$ for the two ice caps are presented in Figs. 3 to 5 (whole ice cap) and Figs. 4 and 6 (changes by elevation).

The glacier-wide rates of elevation change $\left(\mathrm{d} H / \mathrm{d} t_{\text {avg }}\right)$ over the period 1952-2014 were $-0.44 \pm 0.25 \mathrm{~m} \mathrm{a}^{-1}$ for GRIC and $-0.56 \pm 0.19 \mathrm{~m} \mathrm{a}^{-1}$ for TNIC. Similar patterns of historical $\mathrm{d} H / \mathrm{d} t$ are observed for both ice caps (Fig. 6 and $\mathrm{d} H / \mathrm{d} t$ maps), revealing an average surface lowering reaching $-1.1 \pm 0.25 \mathrm{~m} \mathrm{a}^{-1}$ for GRIC and $-0.9 \pm 0.19 \mathrm{~m} \mathrm{a}^{-1}$ for TNIC in the lower altitudes (i.e. the outlet glaciers in the peripheries). Above $250 \mathrm{~m}$ a.s.l., the thinning rate was consistently $0.1 \mathrm{~m} \mathrm{a}^{-1}$ more negative for TNIC than GRIC. The surface thinning was similar for all outlet glaciers of GRIC between 1952 and 2014 (Fig. 3), while on TNIC, a stronger lowering (i.e. $<-1 \mathrm{~m} \mathrm{a}^{-1}$ ) was experienced on the northeast outlet glaciers between 1958/59-2007 (Fig. 5a).

Elevation change rates sharply increased in recent years for both ice caps. On TNIC, the recent (2007-2014) $\mathrm{d} H / \mathrm{d} t_{\text {avg }}$ was $-1.97 \pm 0.40 \mathrm{ma}^{-1}$, a rate $\sim 5.6$ times as negative as the rate of $-0.35 \pm 0.22 \mathrm{ma}^{-1}$ measured between 1958/59 and 2007. The acceleration of the thinning rate was particularly pronounced at lowermost elevations $\left(-6.7 \pm 0.40 \mathrm{ma}^{-1}\right.$ between 2007 and 2014 vs. $-0.9 \pm 0.22 \mathrm{~m} \mathrm{a}^{-1}$ between $1958 / 59$ and 2007), but was also unambiguously observed in the upper sections of the accumulation area $\left(-1.7 \pm 0.40 \mathrm{~m} \mathrm{a}^{-1}\right.$ between 2007 and 2014 vs. $-0.3 \pm 0.22 \mathrm{~m} \mathrm{a}^{-1}$ between $1958 / 59$ and 2007).

On GRIC, changes in $\mathrm{d} H / \mathrm{d} t$ were evaluated over the periods 1952-2004 and 2004-2014 using overlapping areas of the 1952 DEM, in situ GPS measurements and ICESat transects (2004), and the Pléiades DEM (2014) (Fig. 4). Because of the lack of data about seasonal surface height fluctuations, no correction was applied to account for the different elevation acquisition periods of 1952 and 2014 (August) and 2004 (March/April). For the 203 points where elevation measurements are available for the 3 years (points superposed with black dots on Fig. 4), the $\mathrm{d} H / \mathrm{d} t$ was up to 6 times more neg-

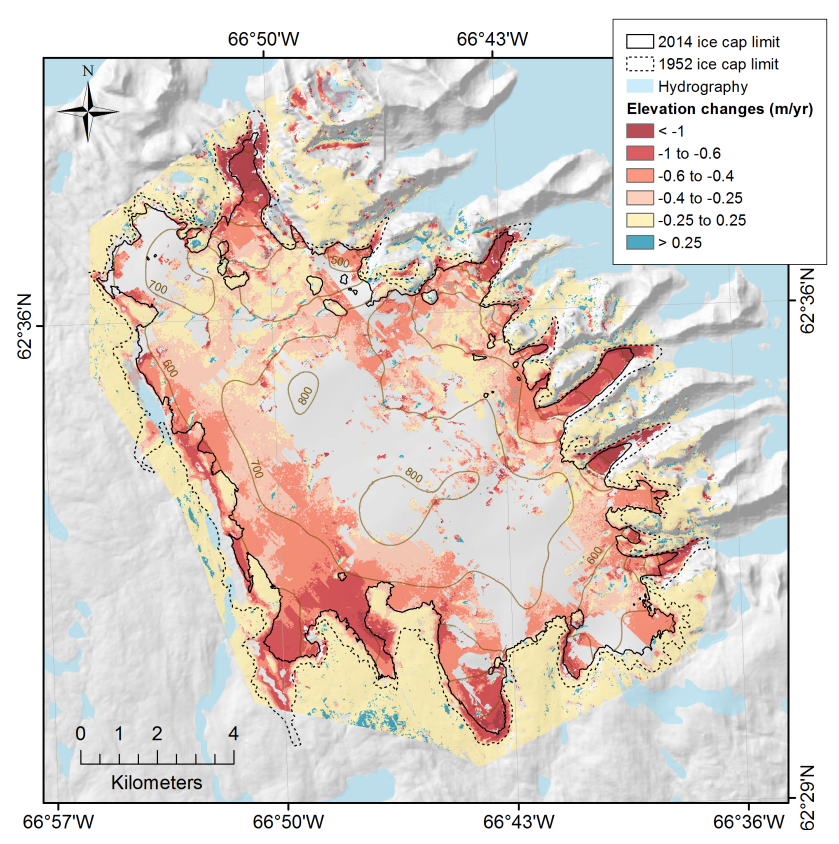

Figure 3. Elevation change rates $\left(\mathrm{ma}^{-1}\right)$ on Grinnell Ice Cap between August 1952 (Aerial photo DEM) and August 2014 (Pléiades DEM). For this figure as well as for the next ones, no color (i.e. hillshade is visible) represents no data.

ative over the 2004-2014 period $\left(-1.47 \mathrm{~m} \mathrm{a}^{-1}\right)$ than over the 1952-2004 period $\left(-0.25 \mathrm{~m} \mathrm{a}^{-1}\right)$.

Additionally, elevation changes measured between ICESat repeat track transects and the Pléiades DEMs over both GRIC and TNIC between 2003 and 2014 are shown in Fig. 7. This analysis reveals a similar range of variability of annual elevation changes between both ice caps during the 2003-2007 interval and a coherent pattern of seasonal to inter-annual fluctuations. The absolute difference in elevation change between 2003 and 2014 for the two ice caps (total thinning of $\sim 11 \mathrm{~m}$ for GRIC vs. $\sim 16 \mathrm{~m}$ for TNIC) is likely to be at least partly explained by the fact that ICESat transects covering GRIC were located at higher altitudes (mean: $\sim 65 \mathrm{~m}$ higher) than those over TNIC.

\subsection{Mass balances}

Mass balances for both ice caps are summarized in Table 2. Between 1952 and 2014, a mass balance of $-0.37 \pm 0.21 \mathrm{~m} \mathrm{a}^{-1}$ w.e. was estimated for GRIC. For TNIC, the historical mass balance (1958/59-2014) was more negative at $-0.47 \pm 0.16 \mathrm{~m} \mathrm{a}^{-1}$ w.e. The mass loss rate for the period 2007-2014 was 5.9 times greater (mass balance: $-1.77 \pm 0.36 \mathrm{~m} \mathrm{a}^{-1}$ w.e.) than that for the period $1958 / 59-$ 2007 (mass balance: $-0.30 \pm 0.19 \mathrm{~m} \mathrm{a}^{-1}$ w.e.). As previously discussed (Sect. 5.2), GRIC has likely experienced a similar acceleration of its mass loss since 2004. 
Table 2. Historical and recent glacier-wide mass balances for both ice caps.

\begin{tabular}{lllcr}
\hline Ice cap & $\begin{array}{l}\text { Time } \\
\text { interval }\end{array}$ & Data set & $\begin{array}{r}\text { Data } \\
\text { voids } \\
(\%)\end{array}$ & $\begin{array}{c}\text { Mass balance } \\
\left(\mathrm{m} \mathrm{a}^{-1} \text { w.e. }\right)\end{array}$ \\
\hline Grinnell & $1952-2014$ & Photogrammetric DEM and Pléiades DEM & 34 & $-0.37 \pm 0.21$ \\
\hline \multirow{3}{*}{ Terra Nivea } & $1958 / 59-2014$ & CDED and Pléiades DEM & 36 & $-0.47 \pm 0.16$ \\
& $1958 / 59-2007$ & CDED and ASTER DEM & 21 & $-0.30 \pm 0.19$ \\
& $2007-2014$ & ASTER DEM and Pléiades DEM & 29 & $-1.77 \pm 0.36$ \\
\hline
\end{tabular}

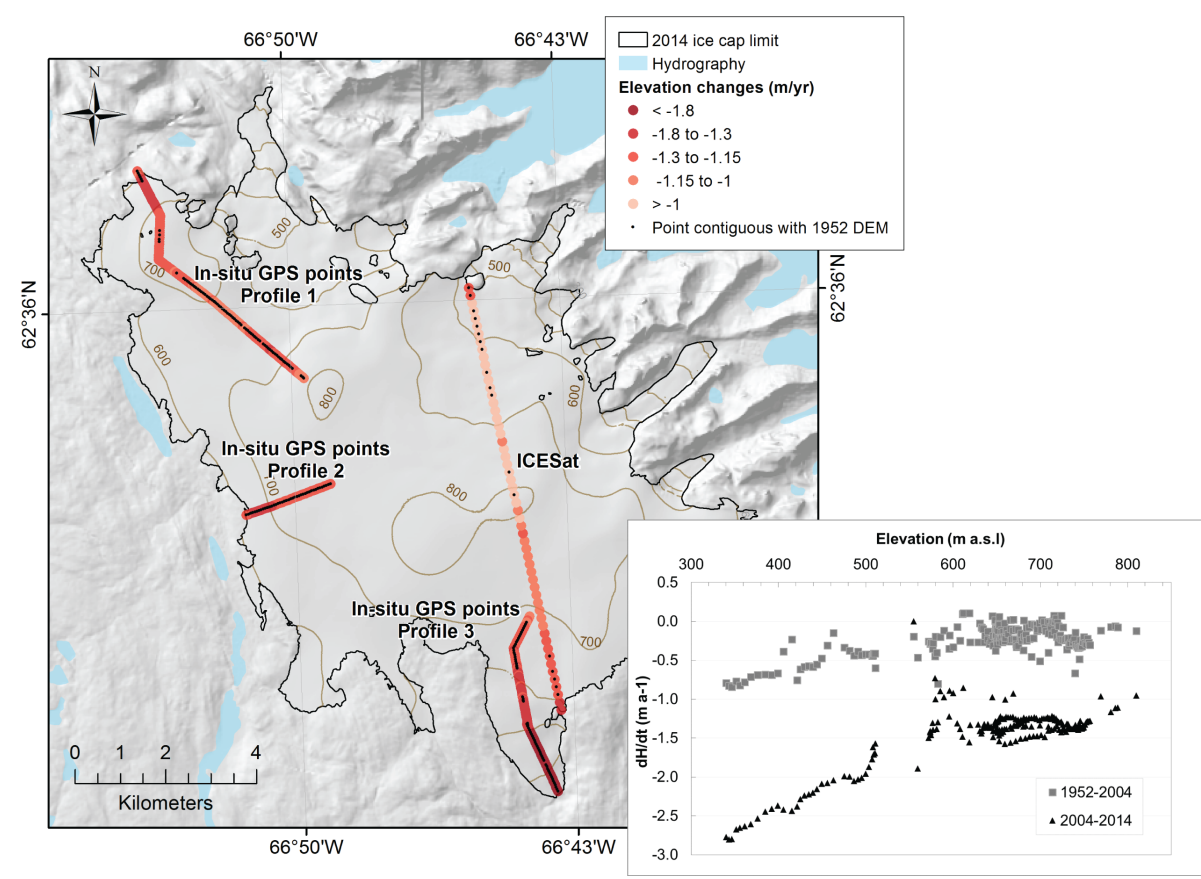

Figure 4. Elevation change rates $\left(\mathrm{m} \mathrm{a}^{-1}\right)$ on Grinnell Ice Cap between March/April 2004 (ICESat and in situ GPS points) and August 2014 (Pléiades DEM). Bottom right graph shows historical (1952-2004) and recent (2004-2014) rates of elevation changes along the 203 points contiguous with the 1952 DEM (represented as black dots on the map).

\section{Discussion}

\subsection{Pléiades as a tool for photogrammetric GCPs collection}

In many regions of the world, vast archives of historical aerial photographs represent a potential gold mine for glaciologists in order to document multi-decadal volumetric change of glaciers and ice caps (e.g. Soruco et al., 2009; Zemp et al., 2010). DEMs generated from these aerial photographs allows to put the recent glacier variations (satellite era) in a longerterm perspective. However, these data remain difficult to exploit due to the logistical difficulties involved in the field collection of accurate and well-distributed GCPs in the remote high latitude/altitude regions. Field GCPs were also lacking for the two ice caps studied here. Instead, we took advantage of the very high resolution of the Pléiades imagery $(0.7 \mathrm{~m})$ and the vertical precision of the derived DEMs $(\sim 1 \mathrm{~m})$ to collect a sufficient number of GCPs for the adjustment of the stereo-model. GCPs were collected on well-defined features that were clearly identifiable on both the Pléiades imagery and the old aerial photos (Fig. 8, yellow arrow). GCP residuals of $\sim 2-3 \mathrm{~m}$ in average were obtained after the block bundle adjustment, and a DEM vertical precision of $\sim 5 \mathrm{~m}(\mathrm{SD})$ was measured with a few ICESat points available over icefree terrain. This is a satisfactory result given that the aerial photos used here were affected by film distortions that could not be corrected. Our results demonstrate the usefulness of Pléiades stereo-images and DEMs to collect accurate GCPs for photogrammetric processing of old aerial photographs in remote environments. Furthermore, the very fine resolution of Pléiades can help to improve the accuracy of nunataks and/or whole ice caps delimitation, especially when compared to the frequently used Landsat images (Fig. 8). 

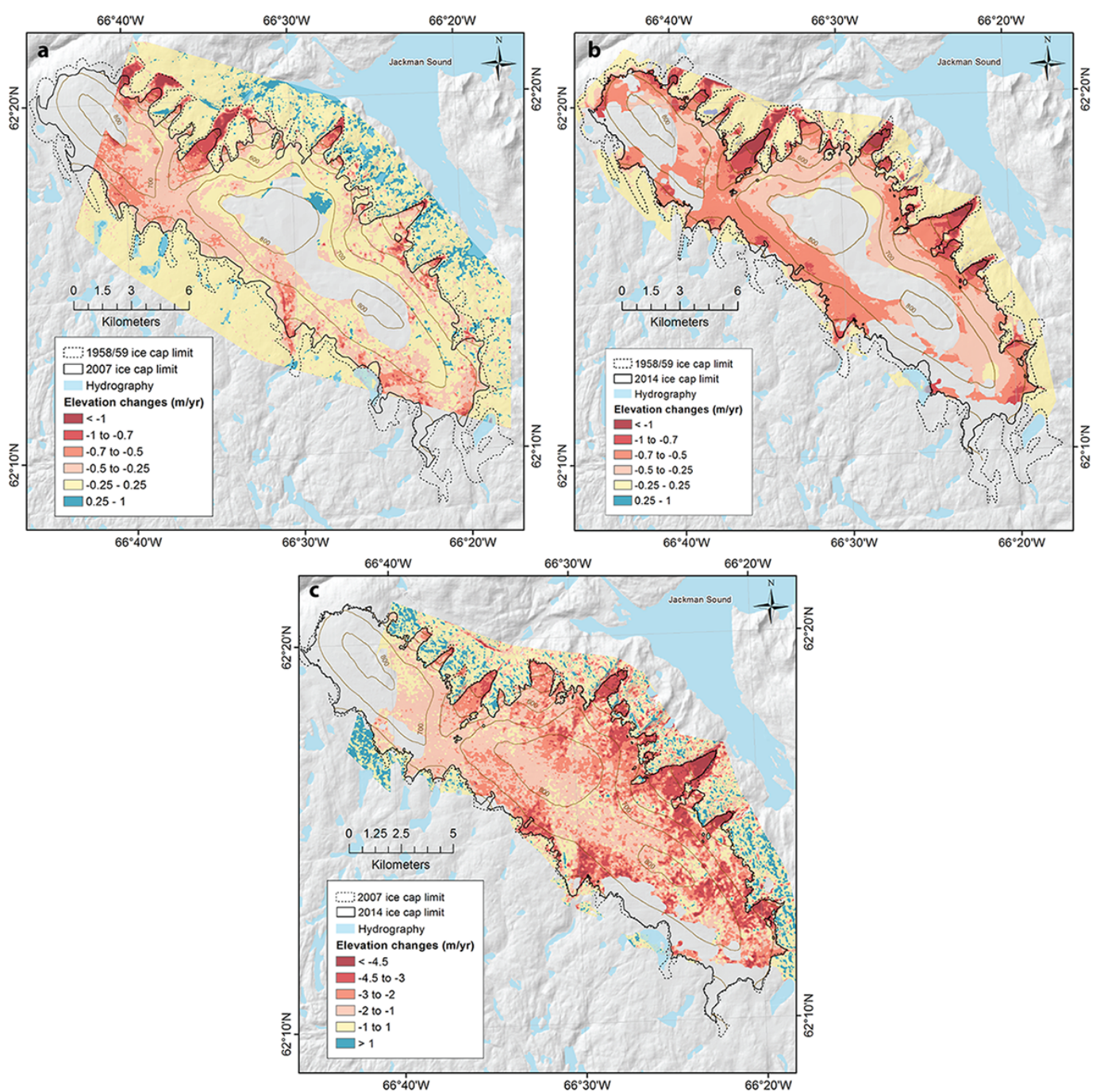

Figure 5. (a) Elevation change rates (dH/dt, $\mathrm{ma}^{-1}$ ) on Terra Nivea Ice Cap (TNIC) between 1958/59 (CDED) and 2007 (ASTER DEM). (b) $\mathrm{d} H / \mathrm{d} t$ on TNIC between 1958/59 (CDED) and 2014 (Pléiades DEM). (c) $\mathrm{d} H / \mathrm{d} t$ on TNIC between 2007 (ASTER DEM) and 2014 (Pléiades DEM). Note a different color scale for the lower panel (c).
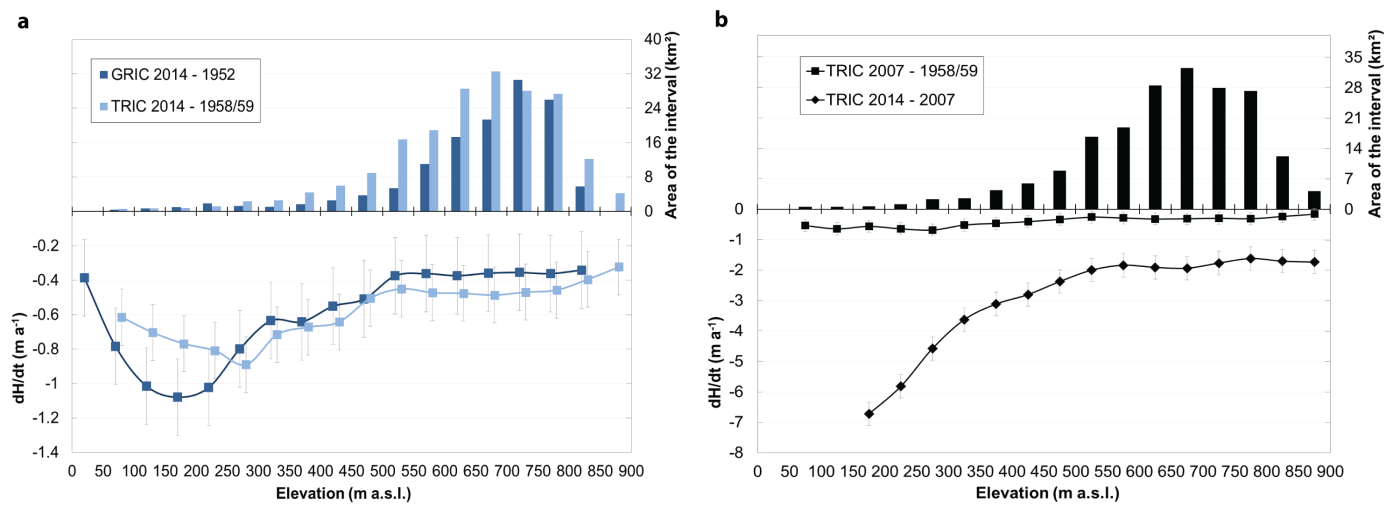

Figure 6. (a) Historical averaged elevation change rates ( $\mathrm{d} H / \mathrm{d} t_{\mathrm{avg}}$ ) measured for GRIC (1952-2014) and TNIC (1958/59-2014) for each $50 \mathrm{~m}$ elevation band. (b) Historical (1959-2007) and recent (2007-2014) $\mathrm{d} H / \mathrm{d} t_{\text {avg }}$ for each $50 \mathrm{~m}$ elevation band on TNIC. The error margins are the elevation change measurement uncertainties determined in Sect. 4.4.3. 

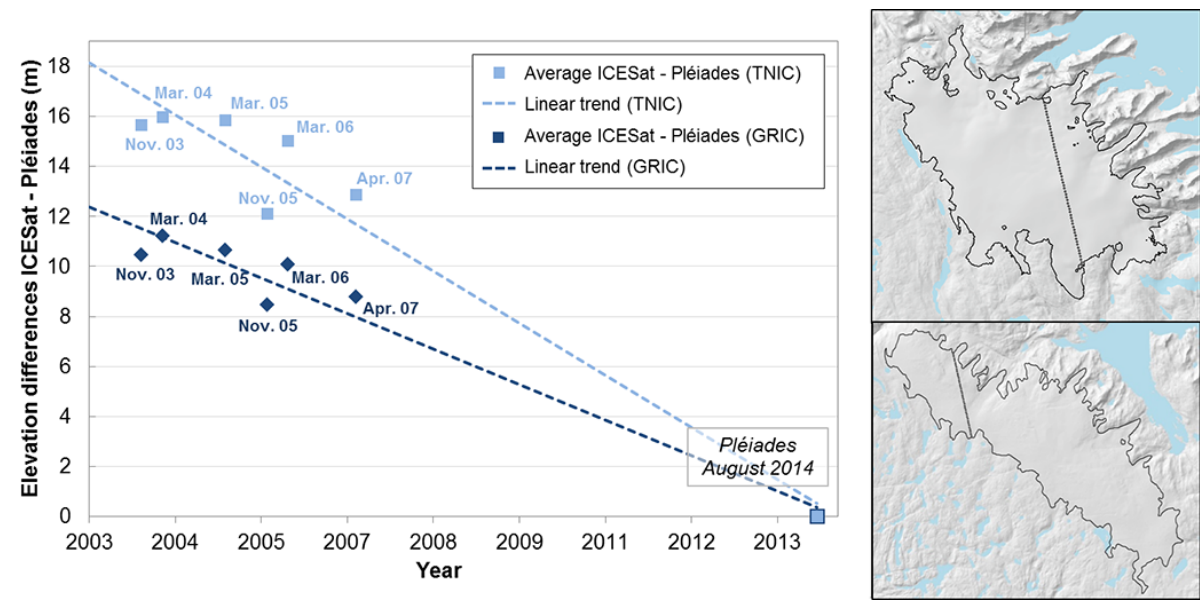

Figure 7. Recent elevation differences on GRIC and TNIC measured between the Pléiades DEMs (2014) and ICESat altimetric points (2003 to 2007). Only the complete ICESat tracks available for both ice caps were used. The trend lines indicate the mean rate of elevation changes along these two ICESat reference tracks and are $\sim-1.1 \mathrm{~m} \mathrm{a}^{-1}$ for GRIC and $\sim-1.6 \mathrm{~m} \mathrm{a}^{-1}$ for TNIC. Transects location for each ice cap is shown on the inset maps (top for GRIC and bottom for TNIC).
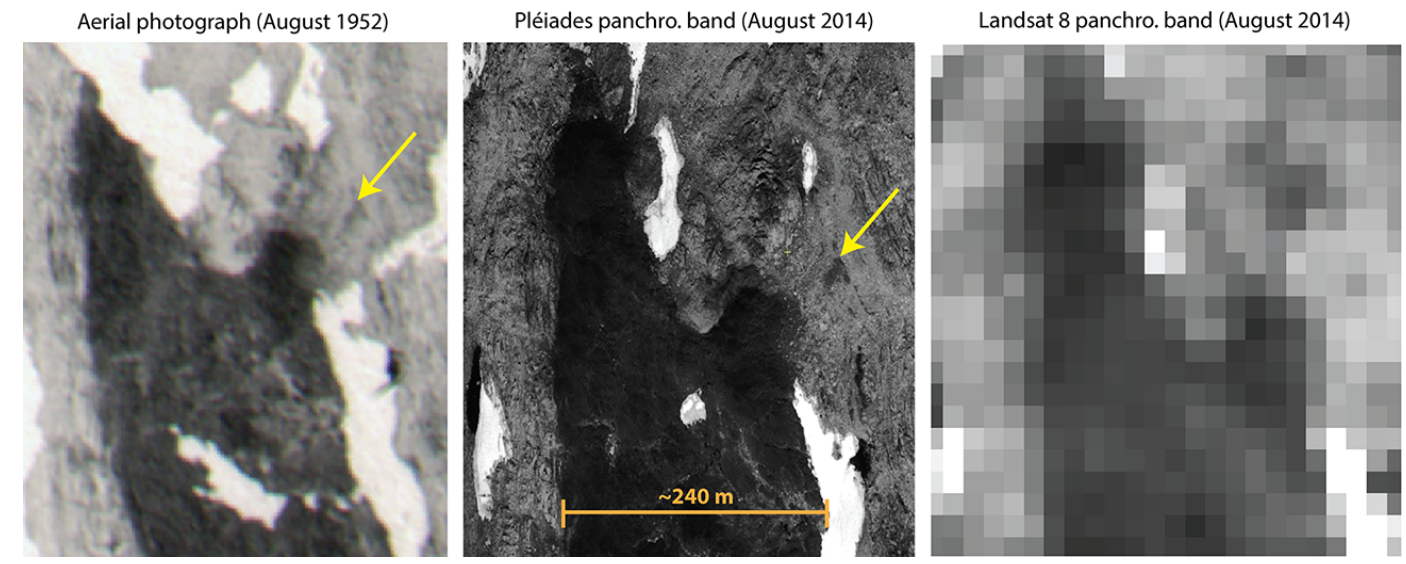

Figure 8. Representation of the same geomorphological feature on ice-free terrain surrounding GRIC using three different technologies, namely an aerial photography (August 1952), a Pléiades panchromatic band (3 August 2014) and a Landsat 8 panchromatic band (15 August 2014). Note the very fine resolution of the Pléiades panchromatic band $(70 \mathrm{~cm})$, in comparison to the Landsat 8 panchromatic band $(15 \mathrm{~m})$, allowing to retrieve bedrocks and ice-free features on archives aerial photos and thus to collect GCPs (e.g. at the bedrock localised by the yellow arrow).

\subsection{Comparison to other studies}

Our estimates of shrinkage for GRIC and TNIC can be compared with other studies from Baffin Island to verify the coherence of results and get a more complete picture of the pattern of glacier changes across this vast region.

Sharp et al. (2014) reported rates of areal change for TNIC of up to $-0.66 \mathrm{~km}^{2} \mathrm{a}^{-1}$ (197 to $169 \mathrm{~km}^{2}$ ) between 1958 and 2000, while our own results give a nearly identical figure of $-0.59 \pm 0.03 \mathrm{~km}^{2} \mathrm{a}^{-1}\left(196.2 \pm 9.9 \mathrm{~km}^{2}\right.$ to $173.2 \pm 8.5 \mathrm{~km}^{2}$ ) over this similar period. For GRIC, however, the shrinkage rate of $-0.36 \mathrm{~km}^{2} \mathrm{a}^{-1}\left(135\right.$ to $\left.120 \mathrm{~km}^{2}\right)$ reported by Sharp et al. (2014) over the period 1958-2000 is nearly 4 times more negative than our own figure of
$-0.10 \pm 0.01 \mathrm{~km}^{2} \mathrm{a}^{-1}$ for $1952-1999\left(131.8 \pm 6.6 \mathrm{~km}^{2}\right.$ to $126.9 \pm 6.3 \mathrm{~km}^{2}$ ). Way (2015) recently reported that between 1973-1975 and 2010-2013, the area of TNIC decreased by $22 \%\left(199.1 \mathrm{~km}^{2}\right.$ to $\left.154.8 \pm 7.5 \mathrm{~km}^{2}\right)$, while that of GRIC reduced by $18 \%\left(134.3 \mathrm{~km}^{2}\right.$ to $\left.110 \pm 0.9 \mathrm{~km}^{2}\right)$. Although results slightly differ between these studies, our results agree within reported errors (when given). We hypothesize that those small disparities could be explained by the errors of interpretation due to snow patches around the ice caps, and/or by the different spatial resolutions and acquisition dates of the data used in the different studies (Paul et al., 2013). A comparison of the areal declines of GRIC and TNIC with those of other Baffin Island ice caps was already conducted in Way (2015) and is thus not presented here. 
Gardner et al. (2012) estimated that the average mass loss rate of all glaciers and ice caps on southern Baffin Island (South of $68.6^{\circ} \mathrm{N}$, excluding Penny Ice Cap) increased from $-0.20 \pm 0.05 \mathrm{~m} \mathrm{a}^{-1}$ w.e. to $-0.76 \pm 0.12 \mathrm{~m} \mathrm{a}^{-1}$ w.e. (i.e. a factor of 4) between the periods 1957-2006 and 2003-2009. This acceleration is more than twice that estimated over similar periods for northern Baffin Island glaciers (North of $68.6^{\circ} \mathrm{N}$, excluding Barnes Ice Cap). Barnes Ice Cap itself, located on central Baffin Island at elevations between 400 and $1100 \mathrm{~m}$ a.s.1., recently experienced a strong thinning acceleration (Sneed et al., 2008; Dupont et al., 2012), resulting in a mass loss rate of $-1.08 \pm 0.12 \mathrm{~m} \mathrm{a}^{-1}$ w.e. between 2005 and 2011 (Gardner et al., 2012). The estimated mass loss rate on Penny Ice Cap between 2003 and 2009 is lower, at $-0.52 \pm 0.12 \mathrm{~m} \mathrm{a}^{-1}$ w.e., a difference which Gardner et al. (2012) attribute to its much higher elevation range (up to $\sim 2000 \mathrm{~m}$ a.s.1.). The comparatively large mass loss rates experienced by GRIC and TNIC in the past half-century can be ascribed to differences in size and to the hypsometry of the ice caps, but also possibly to local climatic factors, as described below.

\subsection{Regional context and climatic factors}

The accelerating recession of glaciers and ice caps across the CAA in recent decades, and the concurrent increase in surface melt over the Greenland Ice Sheet, have been ascribed to a sustained atmospheric pressure and circulation pattern that favors the advection of warm air from the northwest Atlantic into the eastern Arctic and over western Greenland (Sharp et al., 2011; Fettweis et al., 2013). This situation has led to warmer, longer summer melt periods on glaciers of the eastern CAA, and this largely accounts for their increasingly negative mass balance (Weaver, 1975; Hooke et al., 1987; Koerner, 2005; Sneed et al., 2008; Gardner and Sharp, 2007; Gardner et al., 2012).

In the southern Baffin Island region, annual and seasonal mean air temperatures have generally increased since 1948 (except in the spring), but not monotonically (Vincent et al., 2015). At Iqaluit, seasonal trends from 1948 to $\sim 1990$ were non-significant or slightly negative (spring). Thereafter, temperatures rose, particularly in autumn (SON; $+0.8^{\circ} \mathrm{Cdecade}^{-1}$ ) and winter (DJF; $+2.9^{\circ} \mathrm{C} \mathrm{decade}^{-1}$ ), both of these trends being significant at the $95 \%$ level $(p<0.05)$, even when autocorrelation is accounted for (Ebisuzaki, 1997). Climate records from stations further south (e.g. Resolution Island, $61.5^{\circ} \mathrm{N}$ ) are unfortunately too discontinuous to allow quantification of temperature trends on Meta Incognita Peninsula, but these are probably close to those observed in Iqaluit. Although GRIC and TNIC are only separated by $17 \mathrm{~km}$, they did not experience the same historical and recent rates of shrinkage and mass loss (see the Sect. 5), and part of the difference is likely due to differences in hypsometry, which strongly influences the response of glaciers to a given climate forcing (Oerlemans et al., 1998;
Davies et al., 2012; Hannesdóttir et al., 2015). GRIC lies at a slightly higher altitude than TNIC, with $77 \%$ of its area above $600 \mathrm{~m}$ a.s.l., compared to $68 \%$ for the TNIC, and is therefore expected to have a slightly less negative mass balance, as our observations confirm.

A factor that may have indirectly contributed to the accelerating rate of glacier recession on southernmost Baffin Island is the decline in summer sea ice cover in this region (Fig. 9b), one of the steepest observed across the entire CAA (up to $-16 \%$ decade $^{-1}$ since 1968; Tivy et al., 2011). In the Hudson Bay, Hudson Strait, Foxe Basin region, up to $70-80 \%$ of the sea ice decline since 1980 has been attributed to warmer spring and/or autumn surface air temperature, wind forcing accounting for the balance (Hocheim and Barber, 2014). The retreating sea ice cover in Hudson Strait, immediately south of Meta Incognita Peninsula, has been accompanied by a particularly large rise in surface air temperature during autumn months (SON) during or after the sea ice cover minimum, and the rate of autumn warming between 1980 and $2010\left(0.15^{\circ} \mathrm{Ca}^{-1}\right)$ is estimated to have been three times greater than the mean between 1950 and $2010\left(0.05^{\circ} \mathrm{Ca}^{-1}\right.$; Hocheim and Barber, 2014). A consequence of the sea ice retreat in this sector has been to increase the net solar flux absorbed annually at the sea surface at an estimated average rate of $\geq 0.8 \mathrm{~W} \mathrm{~m}^{-2} \mathrm{a}^{-1}$ over the period 1984-2006, and probably faster after the mid-1990s when sea ice decline accelerated (Matsoukas et al., 2010; Hocheim and Barber, 2014). Meanwhile, the temperature record from Iqaluit (Fig. 9a) indicates that while the cumulative sum of positive degree-days (PDD) during the glacier ablation season (April-November) was relatively constant prior to 1990 (no significant trend), it increased at a rate of $\sim 3.8$ degreeday $\mathrm{a}^{-1}(p<0.05)$ after 1990. The clearest increases in PDD occurred between summer and autumn (June to October: 0.24 to 1.46 degree-day $\mathrm{a}^{-1} ; p<0.05$ ), while trends in spring months (April and May) were comparatively very slight or negligible. These observations suggest that while rising summertime temperature undoubtedly remain the main driver for the mass losses of GRIC and TNIC over recent decades (Gardner et al., 2012), the annual mass loss rate could be enhanced by a lengthening of the melt season into the autumn linked to the later freeze-up in Hudson Strait (Hocheim and Barber, 2014). The early autumn weeks, in particular, are a period during which ice-free, open waters surrounding Meta Incognita Peninsula are a large local source of heat to the lower troposphere, while the frequent low-level cloud cover in this season may contribute a further downwelling longwave radiation flux (Dunlap et al., 2007). In this respect, the situation for GRIC and TNIC could differ from that of Barnes Ice Cap $\left(70^{\circ} \mathrm{N}\right)$ on central Baffin Island, where the lengthening of the melt season has been attributed to more frequent early spring thaw events (Dupont et al., 2012). Spaceborne monitoring of the melt duration over GRIC and TNIC by passive microwave sensing would help to verify if these 

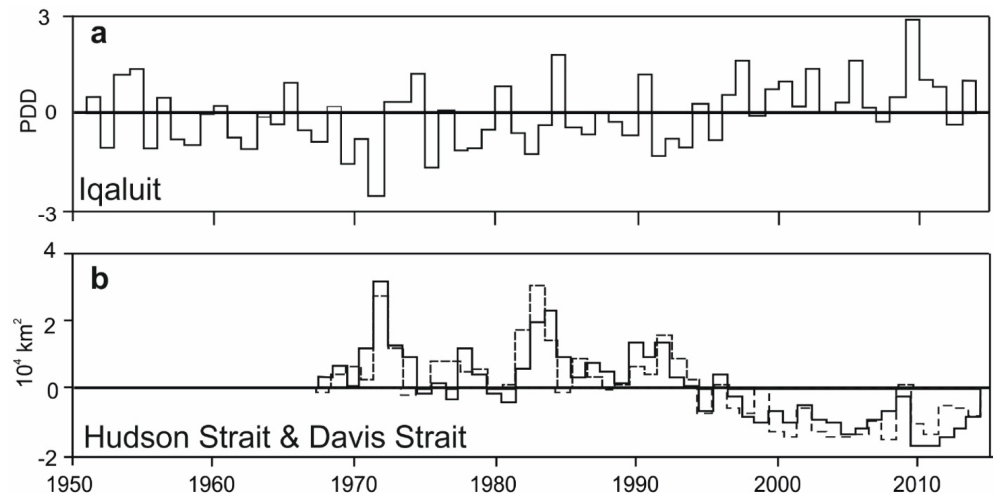

Figure 9. (a) Annual anomalies in total positive degree-days (PDD) recorded from April to November at the Iqaluit weather station, 1952 to 2014, based on Homogenized Canadian Historical Climate Data (Vincent et al., 2015). (b) Anomalies in total sea-ice covered area during the summer and autumn (25 June-19 November) over Hudson Strait (full line) and Davis Strait (dashed line), 1968-2014. Data provided by the Canadian Ice Service. For region boundaries, see Tivy et al. (2011), Fig. 4.

two glacierized sectors of Baffin Island respond to regional warming in different ways.

\section{Conclusions}

This paper highlighted historical and recent trends in area, elevation and mass changes for the two southernmost ice caps of the Canadian Arctic Archipelago, Grinnell and Terra Nivea Ice Caps. Our analysis is based on multiple data sets and uses an original approach where ground control points for the photogrammetric processing of old aerial photographs are derived from sub-meter resolution Pléiades satellite stereo-images. This approach takes full advantage of the highly precise Pléiades products and represents an important advance for eventually unlocking the vast archives of historical aerial photographs.

Results show that the areal extent of TNIC is $34 \%$ smaller in 2014 when compared to the end of the 1950's extent, while GRIC shrank by nearly $20 \%$ between 1952 and 2014. Both ice caps also experienced an acceleration of their shrinkage rates since the beginning of the 21 st century.

The historical glacier-wide mass balance for GRIC was estimated to be $-0.37 \pm 0.21 \mathrm{~m} \mathrm{a}^{-1}$ w.e. (19522014) and slightly more negative for TNIC at $-0.47 \pm 0.16 \mathrm{~m} \mathrm{a}^{-1}$ w.e. (1958/59-2014). Between 2007 and 2014, the mass balance of TNIC was of $-1.77 \pm 0.36 \mathrm{ma}^{-1}$ w.e., a rate 5.9 as negative as the mass balance of $-0.30 \pm 0.19 \mathrm{~m} \mathrm{a}^{-1}$ w.e. measured between $1958 / 59$ and 2007. This is also twice as negative as the average mass balance obtained between 2003 and 2009 for other larger ice caps in the southern part of Baffin Island (Gardner et al., 2012).

The 2007-2014 mass balance of TNIC is among the most negative multi-annual glacier-wide mass balances measured to date, comparable to other negative values observed in the southern mid-latitudes (e.g. Willis et al., 2012; Berthier et al.,
2009) or in southeast Alaska (Trüssel et al., 2013). Given the absence of calving glaciers for TNIC, its high rate of mass loss can only be explained by negative surface mass balance due to an ELA that, for most years, is above the maximum ice cap altitude. Nonetheless, this similarity in rate of mass loss underlines the strong sensitivity of maritime low-elevation ice bodies to the currently observed climate change at midlatitudes and in polar regions (Hock et al., 2009). The recent acceleration of ice cap wastage on Meta Incognita Peninsula is linked to a strong near-surface regional warming and a lengthening of the melt season into the autumn that may be reinforced by sea ice cover reduction and later freeze-up in Hudson Strait and nearby marine areas.

Acknowledgements. This paper is dedicated to Gunnar Østrem (PhD Stockholm Univ., 1965) a tireless pioneer in the study of mountain and Arctic glaciers across Canada, who surveyed GRIC in the early 1990s. Charles Papasodoro acknowledges support from the Fond Québécois de Recherche en Nature et Technologies (FQRNT) fellowship program and the Centre d'Études Nordiques (CEN) for an internship at LEGOS (Toulouse, France). The 2003-04 field surveys on GRIC were conducted with the able assistance of J.C. Lavergne and C. Kinnard, and logistical support from the Geological Survey of Canada, the Polar Continental Shelf Project, and the Nunavut Research Institute. D. Scott, F. Savopol, C. Armenakis and P. Sauvé (Geomatics Canada) assisted with the GPS data reduction back in 2004. This research was supported by the Natural Sciences and Engineering Research Council of Canada, by the French Space Agency (CNES) through the ISIS and TOSCA programs (Pléiades data) and by the Geological Survey of Canada (field campaign). ASTER and Landsat data were obtained free of charge thanks respectively to the GLIMS program (NSIDC) and USGS.

Edited by: J. O. Hagen 


\section{References}

Andrews, J. T., Holdsworth, G., and Jacobs, J. D.: Glaciers of the Arctic Islands. Glaciers of Baffin Island, USGS Professional Paper 1386-J-1, USGS, J162-J198, 2002.

Astrium: Pléiades Imagery User Guide, Airbus Defence and Space, Geo-Information Services, Toulouse, 2012.

Barrand, N. E., Murray, T., James, T. D., Barr, S. L., and Mills, J. P.: Instruments and Methods Optimizing photogrammetric DEMs for glacier volume change assessment using laser-scanning derived ground-control points, J. Glaciol., 55, 106-116, 2009.

Berthier, E. and Toutin, T.: SPOT5-HRS digital elevation models and the monitoring of glacier elevation changes in North-West Canada and South-East Alaska, Remote Sens. Environ., 112, 2443-2454, doi:10.1016/j.rse.2007.11.004, 2008.

Berthier, E., Le Bris, R., Mabileau, L., Testut, L., and Rémy, F.: Ice wastage on the Kerguelen Islands $\left(49^{\circ} \mathrm{S}, 69^{\circ} \mathrm{E}\right)$ between 1963 and 2006, J. Geophys. Res., 114, F03005, doi:10.1029/2008JF001192, 2009.

Berthier, E., Vincent, C., Magnússon, E., Gunnlaugsson, Á. P., Pitte, P., Le Meur, E., Masiokas, M., Ruiz, L., Pálsson, F., Belart, J. M. C., and Wagnon, P.: Glacier topography and elevation changes derived from Pléiades sub-meter stereo images, The Cryosphere, 8, 2275-2291, doi:10.5194/tc-8-2275-2014, 2014.

Blake, W.: Studies of the Grinnell Glacier, Baffin Island, Arctic, 6, 167, 1953.

Cogley, J. G., Hock, R., Rasmussen, L. A., Arendt, A. A., Bauder, A., Braithwaite, R. J., Jansson, P., Kaser, G., Möller, M., Nicholson, L., and Zemp, M.: Glossary of Glacier Mass Balance and Related Terms, IHP-VII Technical Documents in Hydrology No. 86, IACS Contribution No. 2, UNESCO-IHP, Paris, 114 pp., 2011.

Comiso, J. C. and Hall, D. K.: Climate trends in the Arctic as observed from space, Wiley Interdiscip. Rev. Clim. Change, 5, 389409, doi:10.1002/wcc.277, 2014.

Das, I., Hock, R., Berthier, E. and Lingle, C. S.: 21st-century increase in glacier mass loss in the Wrangell Mountains, Alaska, USA, from airborne laser altimetry and satellite stereo imagery, J. Glaciol., 60, 283-293, doi:10.3189/2014JoG13J119, 2014.

Davies, B. J., Carrivick, J. L., Glasser, N. F., Hambrey, M. J., and Smellie, J. L.: Variable glacier response to atmospheric warming, northern Antarctic Peninsula, 1988-2009, The Cryosphere, 6, 1031-1048, doi:10.5194/tc-6-1031-2012, 2012.

Dowdeswell, J.: Debris transport paths and sediment flux through the Grinnell ice cap, Frobisher Bay, Baffin Island, N. W. T., Canada, unpublished MA Thesis, University of Colorado, Boulder, Colorado, 169 pp., 1982.

Dowdeswell, J.: Late Quaternary Chronology for Watts Bay Area, Frobisher Bay, Southern Baffin Island, N. W. T., Canada, Arct. Alp. Res., 16 311-320, 1984.

Dunlap, E., DeTracey, B. M., and Tang, C. C. L.: Short-wave radiation and sea ice in Baffin Bay, Atmos,-Ocean, 45, 195-210, doi:10.3137/ao.450402, 2007.

Dupont, F., Royer, A., Langlois, A., Gressent, A., Picard, G., Fily, M., Cliche, P., and Chum, M.: Monitoring the melt season length of the Barnes Ice Cap over the 1979-2010 period using active and passive microwave remote sensing data, Hydrol. Process., 26, 2643-2652, doi:10.1002/hyp.9382, 2012.
Ebisuzaki, W.: A method to estimate the statistical significance of a correlation when the data are serially correlated, J. Climate, 2, 2147-2153, 1997.

Fox, J. A. and Nuttall, A.-M.: Photogrammetry as a research tool, Photogram. Record, 15, 725-737, 1997.

Fettweis, X., Hanna, E., Lang, C., Belleflamme, A., Erpicum, M., and Gallée, H.: Brief communication "Important role of the midtropospheric atmospheric circulation in the recent surface melt increase over the Greenland ice sheet", The Cryosphere, 7, 241248, doi:10.5194/tc-7-241-2013, 2013.

Fujisada, H., Bailey, G. B., Kelly, G. G., Hara, S., and Abrams, M. J.: ASTER DEM performance, IEEE T. Geosci. Remote, 43, 2707-2714, doi:10.1109/TGRS.2005.847924, 2005.

Gardelle, J., Berthier, E., Arnaud, Y., and Kääb, A.: Region-wide glacier mass balances over the Pamir-Karakoram-Himalaya during 1999-2011, The Cryosphere, 7, 1263-1286, doi:10.5194/tc7-1263-2013, 2013.

Gardner, A. S. and Sharp, M.: Influence of the Arctic Circumpolar Vortex on the Mass Balance of Canadian High Arctic Glaciers, J. Climate, 20, 4586-4598, doi:10.1175/JCLI4268.1, 2007.

Gardner, A. S., Moholdt, G., Wouters, B., Wolken, G. J., Burgess, D. O., Sharp, M. J., Cogley, J. G., Braun, C., and Labine, C.: Sharply increased mass loss from glaciers and ice caps in the Canadian Arctic Archipelago, Nature, 473, 357-360, doi:10.1038/nature10089, 2011.

Gardner, A., Moholdt, G., Arendt, A., and Wouters, B.: Accelerated contributions of Canada's Baffin and Bylot Island glaciers to sea level rise over the past half century, The Cryosphere, 6, 11031125, doi:10.5194/tc-6-1103-2012, 2012.

Gardner, A. S., Moholdt, G., Cogley, J. G., Wouters, B., Arendt, A., Wahr, J., Berthier, E., Hock, R., Pfeffer, W. T., Kaser, G., Ligtenberg, S. R. M., Bolch, T., Sharp, M. J., Hagen, J. O., van den Broeke, M. R., and Paul, F.: A reconciled estimate of glacier contributions to sea level rise: 2003 to 2009 , Science, 340, 852857, doi:10.1126/science.1234532, 2013.

Hannesdóttir, H., Björnsson, H., Pálsson, F., Aðalgeirsdóttir, G. and Guðmundsson, S.: Changes in the southeast Vatnajökull ice cap, Iceland, between $\sim 1890$ and 2010, The Cryosphere, 9, 565-585, doi:10.5194/tc-9-565-2015, 2015.

Hocheim, K. P. and Barber, D. G.: An update on the ice climatology of the Hudson Bay system, Arct. Antarc. Alp. Res., 46, 66-83, 2014.

Hock, R., de Woul, M., Radić, V., and Dyurgerov, M.: Mountain glaciers and ice caps around Antarctica make a large sea-level rise contribution, Geophys. Res. Lett., 36, L07501, doi:10.1029/2008GL037020, 2009.

Hooke, R. L., Johnson, G. W., Brugger, K. A., Hanson, B., and Holdsworth, G.: Changes in mass balance, velocity, and surface profile along a flow line on Barnes Ice Cap, 1970-1984, Can. J. Earth Sci., 24, 1550-1561, 1987.

Huss, M.: Density assumptions for converting geodetic glacier volume change to mass change, The Cryosphere, 7, 877-887, doi:10.5194/tc-7-877-2013, 2013.

Kääb, A.: Glacier volume changes using ASTER satellite stereo and ICESat GLAS laser altimetry. A test study on Edgeøya, Eastern Svalbard, IEEE T. Geosci. Remote, 46, 2823-2830, 2008.

Koerner, R. M.: Mass balance of glaciers in the Queen Elizabeth Islands, Nunavut, Canada, Ann. Glaciol., 41, 417-423, 2005. 
Marti, R., Gascoin, S., Houet, T., Ribière, O., Laffly, D., Condom, T., Monnier, S., Schmutz, M., Camerlynck, C., Tihay, J. P., Soubeyroux, J. M., and René, P.: Evolution of Ossoue Glacier (French Pyrenees) since the end of the Little Ice Age, The Cryosphere Discuss., 9, 2431-2494, doi:10.5194/tcd-9-24312015, 2015.

Matsoukas, C., Hatzianastassiou, N., Fotiadi, A., Pavlakis, K. G., and Vardavas, I.: The effect of Arctic sea-ice extent on the absorbed (net) solar flux at the surface, based on ISCCP-D2 cloud data for 1983-2007, Atmos. Chem. Phys., 10, 777-787, doi:10.5194/acp-10-777-2010, 2010.

Mercer, J. H.: The physiography and glaciology of southernmost of Baffin Island, unpublished PhD Thesis, McGill University, Montreal, Canada, p. 150, 1954.

Mercer, J. H.: The Grinnell and Terra Nivea ice caps, J. Glaciol., 19, 653-656, doi:10.3189/002214356793701910, 1956.

Muller, D. S.: Glacial geology and Quaternary history of southeast Meta Incognita Peninsula, Baffin Island, Canada, MS thesis, University of Colorado, Boulder, Colorado, 211 pp., 1980.

Nuth, C. and Kääb, A.: Co-registration and bias corrections of satellite elevation data sets for quantifying glacier thickness change, The Cryosphere, 5, 271-290, doi:10.5194/tc-5-271-2011, 2011.

Oerlemans, J., Anderson, B., Hubbard, A., Huybrechts, P., Johannesson, T., Knap, W. H., Schmeits, M., Stroeven, A. P., van de Wal, R. S. W., Wallinga, J., and Zuo, Z.: Modelling the response of glaciers to climate warming, Clim. Dynam., 14, 267-274, 1998.

Paul, F., Barrand, N. E., Baumann, S., Berthier, E., Bolch, T., Casey, K., Frey, H., Joshi, S. P., Konovalov, V., Bris, R. Le, Mölg, N., Nosenko, G., Nuth, C., Pope, A., Racoviteanu, A., Rastner, P., Raup, B., Scharrer, K., Steffen, S., and Winsvold, S.: On the accuracy of glacier outlines derived from remote-sensing data, Ann. Glaciol., 54, 171-182, doi:10.3189/2013AoG63A296, 2013.

PCI Geomatics: OrthoEngine User Guide, Richmond Hill, Ontario, Canada, 2013.

Pelto, M. S.: Forecasting temperate alpine glacier survival from accumulation zone observations, The Cryosphere, 4, 67-75, doi:10.5194/tc-4-67-2010, 2010.

Pfeffer, W. T., Arendt, A. A., Bliss, A., Bolch, T., Cogley, J. G., Gardner, A. S., Hagen, J.-O., Hock, R., Kaser, G., Kienholz, C., Miles, E. S., Moholdt, G., Mölg, N., Paul, F., Radić, V., Rastner, P., Raup, B. H., Rich, J., Sharp, M. J. and the Randolph consortium: The Randolph Glacier Inventory: a globally complete inventory of glaciers, J. Glaciol., 60, 537-552, doi:10.3189/2014JoG13J176, 2014.

Schutz, B. E., Zwally, H. J., Shuman, C. A., Hancock, D., and DiMarzio, J. P.: Overview of the ICESat Mission, Geophys. Res. Lett., 32, L21S01, doi:10.1029/2005GL024009, 2005.

Sharp, M., Burgess, D. O., Cogley, J. G., Ecclestone, M., Labine, C., and Wolken, G. J.: Extreme melt on Canada's Arctic ice caps in the 21st century, Geophys. Res. Lett., 38, L11501, doi:10.1029/2011GL047381, 2011.

Sharp, M., Burgess, D. O., Cawkwell, F., Copland, L., Davis, J. A., Dowdeswell, E. K., Dowdeswell, J. A., Gardner, A. S., Mair, D., Wang, L., Williamson, S. N., Wolken, G. J., and Wyatt, F.: Recent glacier changes in the Canadian Arctic, in: Global Land Ice Measurements from Space: Satellite Multispectral Imaging of Glaciers, edited by: Kargel, J. S., Bishop, M. P., Kaab, A., Raup, B. H., and Leonard, G., Springer-Praxis, 205-228, 2014.

Sneed, W. A., Hooke, R. L., and Hamilton, G. S.: Thinning of the south dome of Barnes Ice Cap, Arctic Canada, over the past two decades, Geology, 36, 71-74, doi:10.1130/G24013A.1, 2008.

Soruco, A., Vincent, C., Francou, B., and Gonzalez, J. F.: Glacier decline between 1963 and 2006 in the Cordillera Real, Bolivia, Geophys. Res. Lett., 36, L03502, doi:10.1029/2008GL036238, 2009.

Tingley, M. P. and Huybers, P.: Recent temperature extremes at high northern latitudes unprecedented in the past 600 years, Nature, 496, 201-205, doi:10.1038/nature11969, 2013.

Tivy, A., Howell, E. L., Alt, B., McCourt, S., Chagnon, R., Crocker, G., Carrieres, T., and Yackel, J. J.: Trends and variability in summer sea ice cover in the Canadian Arctic based on the Canadian Ice Service Digital Archive, 1960-2008 and 1968-2008, J. Geophys. Res., 116, C03007, doi:10.1029/2009JC005855, 2011.

Trüssel, B. L., Motyka, R. J., Truffer, M., and Larsen, C. F.: Rapid thinning of lake-calving Yakutat Glacier and the collapse of the Yakutat Icefield, southeast Alaska, USA, J. Glaciol., 59, 149161, doi:10.3189/2013J0G12J081, 2013.

Vaughan, D. G., Comiso, J. C., Allison, I., Carrasco, J., Kaser, G., Kwok, R., Mote, P., Murray, T., Paul, F., Ren, J., Rignot, E., Solomina, O., Steffen, K., and Zhang, T.: Observations: Cryosphere, in: Climate Change 2013: The Physical Science Basis, Contribution of Working Group I to the Fifth Assessment Report of the Intergovernmental Panel on Climate Change, edited by: Stocker, T. F., Qin, D., Plattner, G.-K., Tignor, M., Allen, S. K., Boschung, J., Nauels, A., Xia, Y., Bex, V., and Midgley, P. M., Cambridge University Press, Cambridge, UK and New York, NY, USA, 317-382, 2013.

Vincent, L. A., Zhang, X., Bonsal, B. R., and Hogg, W. D.: Homogenization of daily temperatures over Canada, J. Climate, 15, 1322-1334, 2002.

Vincent, L. A., Zhang, X. Brown, R., Feng, Y., Mekis, E., Milewska, E., Wan, H., and Wang, X.: Observed trends in Canada's climate and influence of low frequency variability modes, J. Climate, 28, 4545-4560, 2015.

Wagnon, P., Vincent, C., Arnaud, Y., Berthier, E., Vuillermoz, E., Gruber, S., Ménégoz, M., Gilbert, A., Dumont, M., Shea, J. M., Stumm, D., and Pokhrel, B. K.: Seasonal and annual mass balances of Mera and Pokalde glaciers (Nepal Himalaya) since 2007, The Cryosphere, 7, 1769-1786, doi:10.5194/tc-7-17692013, 2013.

Way, R.: Multidecadal Recession of Grinnell and Terra Nivea Ice Caps, Baffin Island, Canada, Arctic, 68, 45-53, doi:10.14430/arctic4461, 2015.

Weaver, R. L.: "Boas" Glacier (Baffin Island, N. W. T., Canada) mass balance for the five budget years 1969 to 1974, Arct. Alp. Res., 7, 279-284, 1975.

Willis, M. J., Melkonian, A. K., Pritchard, M. E., and Rivera, A.: Ice loss from the Southern Patagonian Ice Field, South America, between 2000 and 2012, Geophys. Res. Lett., 39, L17501, doi:10.1029/2012GL053136, 2012.

Winsvold, S. H., Andreassen, L. M., and Kienholz, C.: Glacier area and length changes in Norway from repeat inventories, The Cryosphere, 8, 1885-1903, doi:10.5194/tc-8-1885-2014, 2014. 
Zdanowicz, C.: Glacier-climate studies on Grinnell ice cap - Final research report, Nunavut Research Institute, National Glaciology Program, Geological Survey of Canada, Ottawa, Canada, 2007.

Zemp, M., Jansson, P., Holmlund, P., Gärtner-Roer, I., Koblet, T., Thee, P., and Haeberli, W.: Reanalysis of multi-temporal aerial images of Storglaciären, Sweden (1959-99) - Part 2: Comparison of glaciological and volumetric mass balances, The Cryosphere, 4, 345-357, doi:10.5194/tc-4-345-2010, 2010.
Zemp, M., Thibert, E., Huss, M., Stumm, D., Rolstad Denby, C., Nuth, C., Nussbaumer, S. U., Moholdt, G., Mercer, A., Mayer, C., Joerg, P. C., Jansson, P., Hynek, B., Fischer, A., Escher-Vetter, H., Elvehøy, H., and Andreassen, L. M.: Reanalysing glacier mass balance measurement series, The Cryosphere, 7, 12271245, doi:10.5194/tc-7-1227-2013, 2013.

Zwally, H. J., Schutz, B., Abdalati, W., Abshire, J., Bentley, C., Brenner, a., Bufton, J., Dezio, J., Hancock, D., Harding, D., Herring, T., Minster, B., Quinn, K., Palm, S., Spinhirne, J., and Thomas, R.: ICESat's laser measurements of polar ice, atmosphere, ocean, and land, J. Geodyn., 34, 405-445, doi:10.1016/S0264-3707(02)00042-X, 2002. 